\title{
Role of Natural and Anthropogenic Influence on the Salinization of Groundwater from Basement Aquifers in the Middle Part of Mono River Basin, Togo
}

\author{
Kossitse Venyo Akpataku1,2,3*, Masamaéya D. T. Gnazou1, Gbandi Djanéyé-Boundjou', \\ Limam Moctar Bawa1, Serigne Faye ${ }^{2}$
}

${ }^{1}$ Laboratory of Applied Hydrology and Environment, Faculty of Science, University of Lomé, Lomé, Togo

${ }^{2}$ Department of Geology, Faculty of Sciences and Techniques, Cheikh Anta Diop University, Dakar, Senegal

${ }^{3}$ Department of Chemistry, Faculty of Sciences and Techniques, University of Kara, Kara, Togo

Email: *avenyo@gmail.com

How to cite this paper: Akpataku, K.V., Gnazou, M.D.T., Djanéyé-Boundjou, G., Bawa, L.M. and Faye, S. (2020) Role of Natural and Anthropogenic Influence on the Salinization of Groundwater from Basement Aquifers in the Middle Part of Mono River Basin, Togo. Journal of Environmental Protection, 11, 1030-1051.

https://doi.org/10.4236/jep.2020.1112065

Received: November 23, 2020

Accepted: December 20, 2020

Published: December 23, 2020

Copyright $\odot 2020$ by author(s) and Scientific Research Publishing Inc. This work is licensed under the Creative Commons Attribution International License (CC BY 4.0).

http://creativecommons.org/licenses/by/4.0/

\begin{abstract}
This study aimed to identify the role of natural and anthropogenic influence on geochemical processes controlling groundwater salinization in the middle portion of the Mono River basin, Togo. Multivariate statistical analysis, geochemical masse balance modeling, and conventional graphical methods were applied to the chemical dataset obtained from 110 groundwater samples collected during two campaigns (March-May 2011 and April 2014). The results showed that groundwater is predominantly fresh, acidic to circumneutral and mixed cations- $\mathrm{HCO}_{3}^{-}$water types. The proportion of ions $\left(\mathrm{Na}^{+}, \mathrm{K}^{+}, \mathrm{Cl}^{-}\right.$and $\mathrm{SO}_{4}^{2-}$ ) occurring ubiquitously in a saline environment increases substantially with TDS. Two factors, defined as natural and anthropogenic, account for $76.5 \%$ of the hydrochemical dataset variance. Based on the hierarchical cluster analysis, groundwater samples are classified into four clusters that corroborate the factor analysis results and illustrate different hydrochemical evolution stages along a topographically-driven groundwater flow path. The primary natural process contributing to cations and bicarbonate ions is the weathering of silicate minerals and possibly secondary carbonates by infiltrating water enriched with soil $\mathrm{CO}_{2}$ gas. Groundwater salinization indicators including $\mathrm{Cl}^{-}, \mathrm{SO}_{4}^{2-}$ and $\mathrm{NO}_{3}^{-}$, originate from potential sources such as human and animal wastes, agrochemicals, and deforestation. Thermodynamic equilibrium conditions ranged from saturation to oversaturation with respect to quartz, chalcedony, amorphous silica, calcite, dolomite, sepiolite, and talc. In conjunction with the lowering of $\mathrm{CO}_{2}$ partial pressure and evapora-
\end{abstract}


tion, these conditions restrict acidic hydrolysis of primary silicates but magnify the groundwater salinization process in the lower elevation areas where soil crusts' formation is favorable. This study showed the effective use of multivariate statistical analysis and complementary techniques in identifying the significant factors and processes controlling groundwater chemistry.

\section{Keywords}

Mono River Basin, Groundwater, Silicates Weathering, Anthropogenic Contamination, Salinization, Togo

\section{Introduction}

The quality of water resources is a critical factor for domestic, agricultural, industrial uses, and ecological balance maintenance. Hence, water quality improvement in the various aspects of water supply represents essential opportunities to ensure communities' sustainable development by enhancing public health. Hydrological and geological settings are the main natural factors controlling the evolution of water chemistry. They are related to climate, rainfall regime, recharge dynamics, the chemical composition of precipitations, flow conditions, types of rocks and minerals, types of soil, vegetation types and vegetal species, and geomorphological conditions [1] [2] [3].

Nevertheless, significant variations can occur due to anthropogenic inputs from fertilizers, manure, sewage, domestic, and industrial [4]. Another class of anthropogenic impact is groundwater overexploitation. Groundwater pumping can accelerate mineralization processes and the changes in the hydrochemical facies of unconfined aquifers. Furthermore, mixing through downward leakage from the unconfined aquifer may result in a drastic deterioration of the confined groundwater quality [5]. Groundwater salinization can also occur due to the mixing with saline fossil water mobilized by intensive groundwater pumping [6]. It appears that the evaluation of the natural background of the chemical composition of water resources becomes essential for the identification, monitoring, and management of anthropogenic impacts.

This assessment is necessary for the transboundary Basin of Mono River, where investigations on water quality and hydrochemistry have received little attention despite its importance for the socio-economic development of the population in Benin and Togo, West Africa. Its middle part in Togo shelters the Nangbeto dam for power generation and where fishing is practiced [7]. This part characterized by numerous human settlements constitutes one of the mains cereal and cotton production areas in the country [8] and hosts regularly transhumant livestock [9]. All these activities require a high amount of water but may directly or indirectly affect water resources. Cases of high nitrate exceeding the WHO limit of $50 \mathrm{mg} / \mathrm{L}[10]$ and relatively high salinization were often found in 
groundwater during drilling projects in rural areas [11].

Insights into the hydrological and geochemical processes are required for a comprehensive understanding of the evolution of groundwater chemistry. Therefore, the consolidation of knowledge on the hydrochemistry of water resources, aquifer systems' properties, and the involved biological, physical, and geochemical processes has become a high priority concern in the basin. These pieces of knowledge can provide a vital contribution to solve water resources problems. However, the acquired chemical data set for detailed hydrogeochemical studies contain multiples variables.

The treatment of such a dataset implies an adapted methodology to unravel hidden inter-variables relationships and critical pieces of information regarding factors and processes controlling groundwater chemistry even in complex systems. For this purpose, the usefulness of multivariable statistical-based techniques combined with other conventional methods has been proven [3] [12] [13] [14]. The integrated statistical, geochemical, and spatial analysis of hydrochemical data was used efficiently to identify the critical natural and anthropogenic induced processes controlling hydrochemical variations as well as the chemical signature and the locations of anthropogenic influence in the Turkey Creek Basin, Colorado, USA [13]. A similar approach combining geochemical modeling and different complementary multivariate statistical analysis with a detailed assessment of the geological setting was used to identify the hydrological process and geological controls on hydrochemical evolution in the Eromanga and Galilee Basins, Australia [15] and the coastal aquifer system of Douala, Cameroon [16]. Groundwater salinization sources and processes were also enabled, using combined statistics, GIS, and hydrogeochemical investigations [2] [17] [18] [19].

In this study, multivariate statistical analysis was used to identify the impact of natural and anthropogenic factors on groundwater salinization from crystalline basement aquifers system beneath intensive agro-pastoral areas in the middle part of the Mono River Bassin in Togo. The factor analysis and the hierarchical cluster analysis were applied together with conventional diagrams, mass balance modeling, and hydrogeochemical mapping.

\section{Description of the Study Area}

With an area of nearly $24,100 \mathrm{~km}^{2}$, the Mono River Basin extends between latitudes $6^{\circ} 16^{\prime}$ and $9^{\circ} 21^{\prime} \mathrm{N}$, and longitudes $0^{\circ} 42^{\prime}$ and $1^{\circ} 55^{\prime} \mathrm{E}$. It is one of the transboundary basins in West Africa (Figure 1) shared by Togo and Benin in its lower part, while its central to upper parts are mainly in Togo. Two climatic domains are distinct in the Mono Basin: a Sudanian climate domain with a unimodal pluvial regime (May to October) in the upper part, and a Guinean climate domain classified as sub-equatorial with a bimodal rainfall regime (April to July and September to November) in the lower part [20]. The central part of the basin represents the transition zone of these two climatic conditions. However, the rainfall amount is strongly related to topography. The north's borders to the 
West of the basin correspond to the Togo Mountains with elevations above 500 $\mathrm{m}$ asl. The annual rainfall amount decreases from about $1500 \mathrm{~mm}$ to below 1000 $\mathrm{mm}$ in the East and Southeastern parts. Sandy's ferruginous soils (Alfisols) of the semi-arid tropics with low clay content and organic matter dominate the study area [21]. They are widely exploited for maize, cotton, groundnut, sorghum, cowpea, and soya crops.

The geology of the study area includes a variety of basement rocks of the Pan-African Dahomeyide orogenic belt. They consist mainly of micaschists, kyanite- and mica-bearing quartzites, ultrabasic and basic massifs, and gneisso-migmatitic units (Figure 1). Groundwater potential in the study area depends on secondary structures and apertures resulting from the alteration and the tectonic actions [22]. The aquifer system generally has a classical configuration, where a surface altered layer and a fissured horizon overlap on a more or less fractured crystalline basement. Its productivity is low, with yields often less than $5 \mathrm{~m}^{3} / \mathrm{h}$ and frequent transmissivity in the order of $10^{-5} \mathrm{~m}^{2} / \mathrm{s}$ [11].

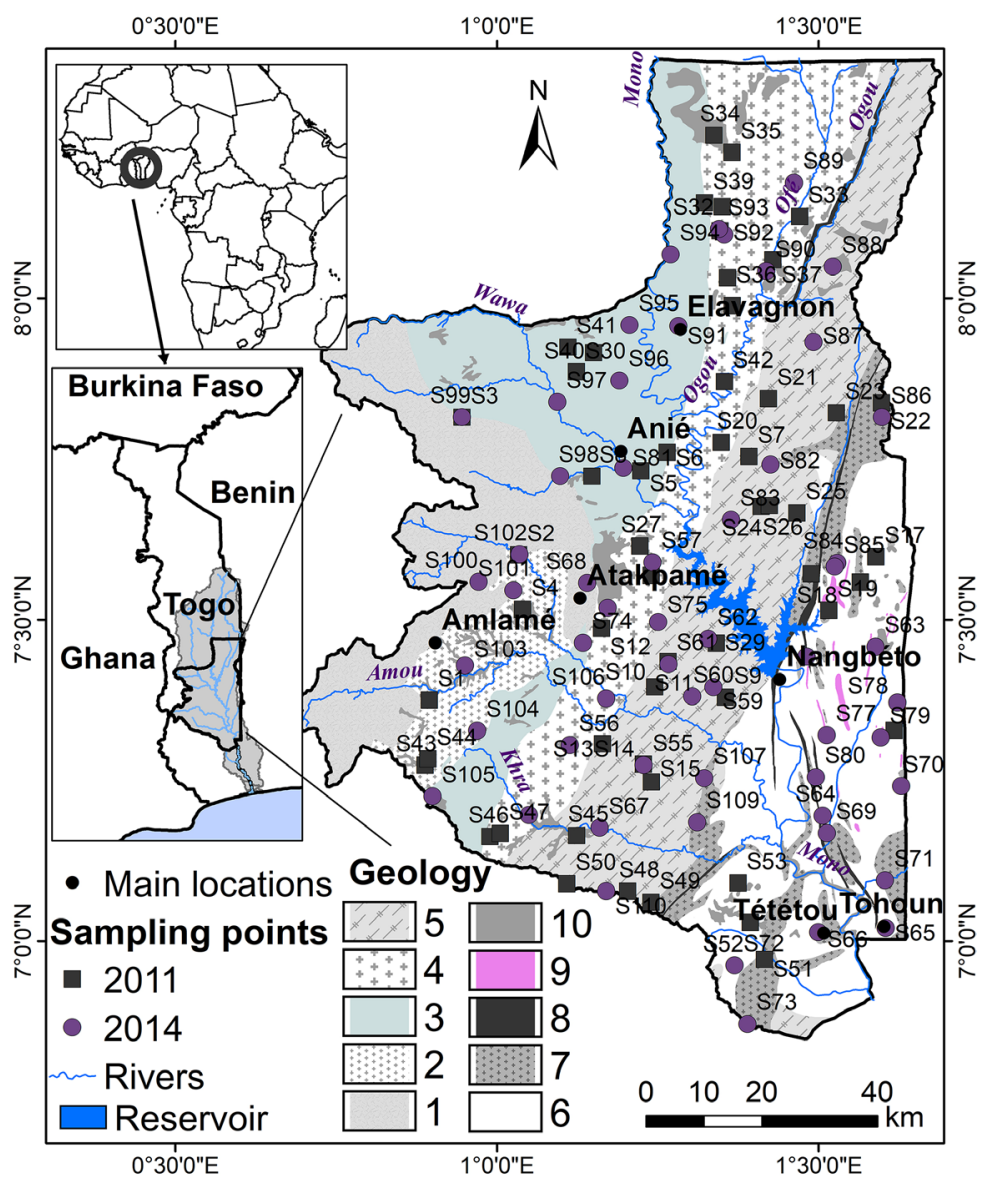

Figure 1. Location of the study area and simplified geology map modified from [22]. Atacora Structural Unit ( 1 = micaschists, kyanite- and mica-bearing quartzites), Gneisso-migmatitic external units ( 2 = granodiorites), Ultrabasic and basic massifs of the suture zone ( 3 = Gneisso-amphibolic series and metadiorites) Gneisso-migmatitic internal units $(4=$ granitic gneiss, $5=$ migmatites, $6=$ dioritic gneiss, $7=$ granitoids, $8=$ mylonites, $9=$ crystalline dolomite $)$ and Quaternary rocks (10 = alluvial deposit and laterites). 


\section{Materials and Methods}

\subsection{Sampling and Analytical Methods}

Hydrochemical data were obtained from 54 boreholes drilled in 2011 (March to May) by the National Water Resource Board [11] and 56 boreholes during a sampling campaign undertaken in April 2014. The selected points cover the geographical extension and the study area's main geologic settings for each campaign. Several volumes of water were removed to purge stagnant water until stabilization of temperature and $\mathrm{pH}$ before the measurement of in situ parameters such as $\mathrm{pH}( \pm 0.1)$, temperature $\left( \pm 1^{\circ} \mathrm{C}\right)$, and electrical conductivity (EC) $( \pm 2 \%, \mu \mathrm{S} / \mathrm{cm})$ using a portable multimeter (HANNA, Instruments). Groundwater samples were collected in $1.5 \mathrm{~L}$ polyethylene bottles. In the field, bottles were rinsed several times with well water. Major ions analyses were performed using the French Association of Standardization methods [23]. The volumetric method for $\mathrm{HCO}_{3}^{-}( \pm 0.6 \mathrm{mg} / \mathrm{L})$ and $\mathrm{Cl}^{-}( \pm 0.5 \mathrm{mg} / \mathrm{L})$, molecular absorption spectrophotometry (JENWAY Spectrophotometer) for $\mathrm{NO}_{3}^{-}, \mathrm{SO}_{4}^{2-}$, and $\mathrm{SiO}_{2}$ with $1 \%$ to $2 \%$ accuracy. Cations were determined using complexometric EDTA titration for $\mathrm{Ca}^{2+}( \pm 0.5 \mathrm{mg} / \mathrm{L})$ and $\mathrm{Mg}^{2+}( \pm 0.24 \mathrm{mg} / \mathrm{L})$, and flame photometry (JENWAY Flame Photometer) for $\mathrm{Na}^{+}$and $\mathrm{K}^{+}$with $0.2 \mathrm{mg} / \mathrm{L}$ as limit of detection for both elements. All Analytical results were validated for charge balance errors (CBE) within the $\pm 10 \%$ range [24].

\subsection{Statistical Analysis}

The multivariate chemical data set obtained from laboratory analysis were submitted to descriptive statistics and multivariate analysis using STATISTICA software. The nonparametric Mann-Whitney U test was used to evaluate the interannual variation of groundwater chemistry [25]. The most popular Q-mode hierarchical cluster analysis (HCA) and the R-mode factor analysis (FA), were used in this study [12] [14] [26]. The HCA detects similarities among water samples chemistry and classifying them into more or less homogeneous and distinct groups. The FA reduces data redundancy and explaining the interrelationships in large numbers of variables by few factors. The mathematical models used for these MSA rely on certain assumptions about the data used. Some key assumptions were assured to validate the results. The variables were firstly log-normalized to meet the normal distribution required. Then, log-normal data are standardized with zero mean and unit standard deviation to assure that outliers are reduced in the dataset. All variables are weighted equally so that the highest magnitude variables will not influence the results. For each variable, the standardized $Z$-scores $\left(Z_{i}\right)$ associated with each observation are computed as follows $Z_{i}=\left(X_{i}-\mu\right) / S$ where $X_{i}$ is the observed data, $\mu$ the mean value, and $S$ the standard deviation of the distribution. The Q-Mode HCA was performed based on Ward's linkage method and the Euclidean distance for similarity measurement. The new variables of factors with eigenvalues greater than one were extracted using the principal component analysis (PCA) and following Kaiser 
Criterion. The retained factors were also submitted to Varimax normalized rotation so that the differences among selected factors become high and then facilitate hydrochemical interpretation.

\subsection{Major Ions Chemistry and Mass Balance Modeling}

The suitability of groundwater for drinking purposes was assessed based on the WHO water quality standards [10]. Piper diagram from GWChart Software was used to display and to identify the main hydrochemical facies. Ionic ratios, binary graphs, and mineral saturation indices (SI) were also used for hydrochemical interpretations. The saturation indices can be calculated as $\mathrm{SI}=\log \left(\mathrm{IAP} / \mathrm{K}_{\mathrm{S}}\right)$, where $\mathrm{K}_{\mathrm{S}}$ is the ion solubility product of minerals and IAP the corresponding ion activities products in groundwater [4]. Due to analytical uncertainties, the saturation state was defined for SI within the \pm 0.5 range. The calculation of partial pressure of $\mathrm{CO}_{2}$ gas and the saturation indices of groundwater samples with respect to minerals was performed using the USGS geochemical code PHREEQC integrated into DIAGRAMMES software.

\section{Results and Discussion}

\subsection{Hydrochemical Characteristics}

The statistical summaries of the measured hydrochemical parameters during both sampling campaigns are presented in Table 1 . Silica was determined only for samples collected in 2014.

Table 1. Statistical summary of the hydrochemical parameters (Number of samples $=110$ except for $\mathrm{SiO}_{2}$ determined only in 2014, $\mathrm{N}=56$ ).

\begin{tabular}{cccccc}
\hline Variable & Minimum & Maximum & Mean & Median & Std. Dev. \\
\hline $\mathrm{T}\left({ }^{\circ} \mathrm{C}\right)$ & 19.0 & 31.0 & 27.8 & 28.1 & 2.3 \\
$\mathrm{pH}(-)$ & 4.1 & 8.3 & 6.9 & 7.0 & 0.6 \\
$\mathrm{EC}(\mu \mathrm{S} / \mathrm{cm})$ & 130 & 2140 & 646 & 545 & 360 \\
$\mathrm{TDS}(\mathrm{mg} / \mathrm{L})$ & 123 & 1622 & 475 & 390 & 276 \\
$\mathrm{Ca}^{2+}(\mathrm{mg} / \mathrm{L})$ & 11.2 & 172.8 & 45.1 & 38.8 & 26.3 \\
$\mathrm{Mg}^{2+}(\mathrm{mg} / \mathrm{L})$ & 2.6 & 89.8 & 27.2 & 22.4 & 18.0 \\
$\mathrm{Na}^{+}(\mathrm{mg} / \mathrm{L})$ & 3.2 & 257.5 & 58.2 & 49.4 & 38.3 \\
$\mathrm{~K}^{+}(\mathrm{mg} / \mathrm{L})$ & 1.1 & 32.5 & 6.5 & 5.9 & 4.1 \\
$\mathrm{HCO}_{3}^{-}(\mathrm{mg} / \mathrm{L})$ & 42.7 & 597.8 & 291.6 & 292.8 & 118.5 \\
$\mathrm{Cl}^{-}(\mathrm{mg} / \mathrm{L})$ & 0.5 & 235.3 & 38.8 & 17.0 & 50.7 \\
$\mathrm{SO}_{4}^{2-}(\mathrm{mg} / \mathrm{L})$ & 1.0 & 187.7 & 20.8 & 5.7 & 36.4 \\
$\mathrm{NO}_{3}^{-}(\mathrm{mg} / \mathrm{L})$ & $<\mathrm{LD}$ & 610.2 & 45.7 & 4.8 & 94.2 \\
$\mathrm{SiO}_{2}(\mathrm{mg} / \mathrm{L})$ & 14.7 & 82.2 & 51.3 & 51.5 & 14.6 \\
\hline
\end{tabular}


The $\mathrm{pH}$ values varied from 4.1 to 8.3 with a mean of $6.9 \pm 0.6$, indicating acidic to nearly neutral water types. The EC and TDS values ranged from 130 to 2140 $\mu \mathrm{S} / \mathrm{cm}$ and 123 to $1622 \mathrm{mg} / \mathrm{L}$ with mean values of $646 \pm 360 \mu \mathrm{S} / \mathrm{cm}$ and $475 \pm$ $276 \mathrm{mg} / \mathrm{L}$, respectively. These values indicate a low to a high level of groundwater mineralization. However, in general, groundwater may be classified as freshwater since TDS is lower than $1000 \mathrm{mg} / \mathrm{L}$ [10]. Generally, concentrations of the major ions except for $24 \%$ of nitrate are within the acceptable WHO recommended ranges for drinking purposes [10]. However, the major ions concentration, EC, and TDS values showed a high standard deviation as a sign of high variance. This observation fits the heterogeneity of geological and hydrogeological settings of the study area. It suggests that groundwater chemistry is subject to spatial variability due to the conjunction of different factors and processes in the study area. Based on the median concentrations (Table 1), the general contribution of anions to groundwater mineralization was in the order of $\mathrm{HCO}_{3}^{-}>$ $\mathrm{Cl}^{-}>\mathrm{SO}_{4}^{2-} \approx \mathrm{NO}_{3}^{-}$, while the contribution of cations was $\mathrm{Na}^{+}>\mathrm{Ca}^{2+}>\mathrm{Mg}^{2+}>$ $\mathrm{K}^{+}$. Silica concentrations ranged $14.7 \mathrm{mg} / \mathrm{L}$ to $82.2 \mathrm{mg} / \mathrm{L}$ with mean value of 51.3 $\pm 14.6 \mathrm{mg} / \mathrm{L}$.

The nonparametric Mann-Whitney $\mathrm{U}$ test comparing two independent groups yielded significant differences $(\mathrm{p}<0.05)$ for EC, TDS, $\mathrm{Mg}^{2+}$, and $\mathrm{Cl}^{-}$between 2011 and 2014, as shown in Figure 2. However, these hydrochemical parameters and other ions showed similar ranges (minimum-maximum). Therefore, the interannual differences observed in data distributions could be coincidental due to local variation in geochemical processes or seasonal due to the interannual variation of rainfall and the water table level [20] [25] [27].
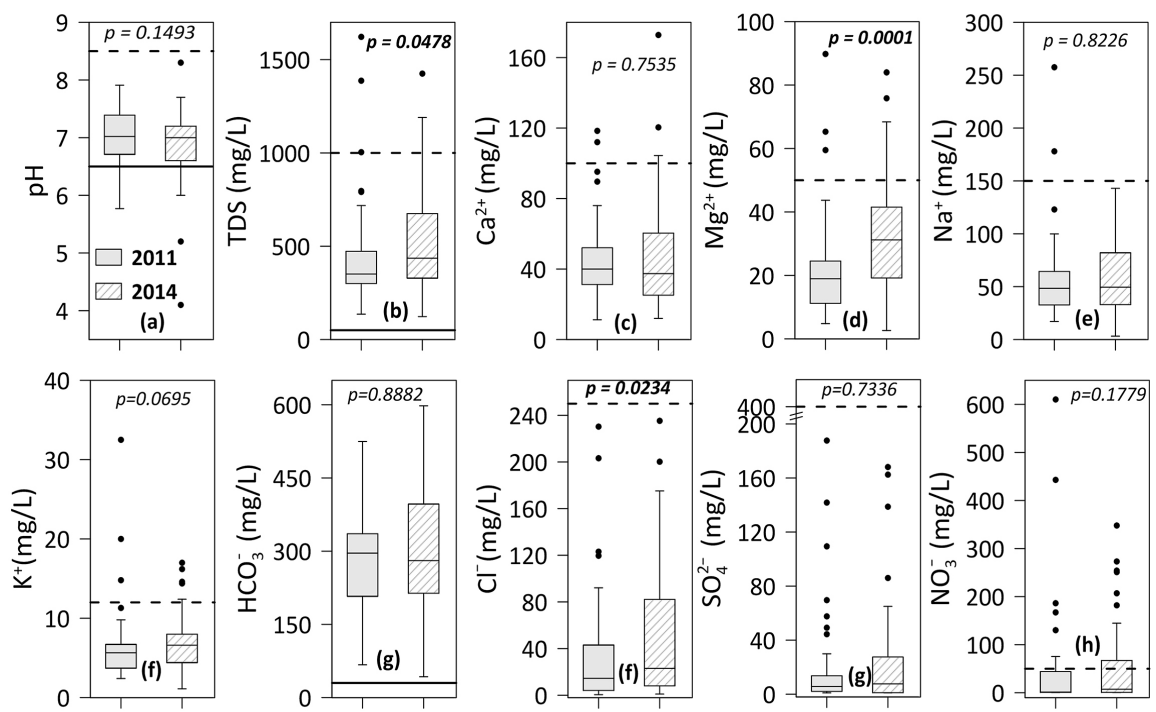

Figure 2. Comparison of selected hydrochemical parameters measured during the two sampling years 2011 and 2014 using boxplot representations. Circles represent outliers. (b) TDS, (d) $\mathrm{Mg}^{2+}$, (f) $\mathrm{Cl}^{-}$and EC (not represented here) present significant differences ( $\mathrm{p}$ $<0.05)$ in data distributions according to Mann-Whitney U-test. WHO (2011) lower limits and upper limits are represented by solid and dash lines, respectively. 
The major ions composition of groundwater is shown in the Piper diagram (Figure 3). Irrespective of sampling years, mixed Ca-Na-Mg- $-\mathrm{HCO}_{3}$ water types predominate while $\mathrm{Na}-\mathrm{HCO}_{3}, \mathrm{Ca}-\mathrm{Na}-\mathrm{HCO}_{3}$, and $\mathrm{Ca}-\mathrm{Mg}-\mathrm{Cl} \mathrm{Na}-\mathrm{Cl}$ water types are accessories. This result fits the silicate minerals dominating in the study area [22] [28] [29]. In 2014, few groundwater samples (seven) were displayed in $\mathrm{Mg}-\mathrm{HCO}_{3}$ and $\mathrm{Mg}-\mathrm{Na}-\mathrm{HCO}_{3}$ hydrochemical facies field (Figure 3), showing an abundance of $\mathrm{Mg}^{2+}$. These samples were not collected in 2011 and could not permit a seasonal interpretation. However, the location of four (S91, S95, S98, and S105) of these seven points in the suture zone (Figure 1) dominated by ultramafic and mafic rocks together with kyanite and phengite bearing quartzites, [22] [30], suggest the control of host rock dependent water chemistry on the abundance of $\mathrm{Mg}^{2+}$ in these samples.

\subsection{Inter-Ionic Relationship}

Correlation analysis was performed to identify the relationship between the various hydrochemical parameters. The Spearman rank-order correlation results using a pre-established significance level of 0.05 are presented in Table 2. The EC shows significant correlations with all variables suggesting multiples sources of groundwater mineralization. The $\mathrm{pH}$ and $\mathrm{HCO}_{3}^{-}$return a good correlation. Besides, $\mathrm{HCO}_{3}^{-}$is correlated with all major cations, suggesting possibly carbonic acid-driven hydrolysis of endogenous silicate minerals dominating in basement roks as a vital source of cations and alkalinity in groundwater [31].

The neutral anions $\left(\mathrm{Cl}^{-}, \mathrm{SO}_{4}^{-}\right.$and $\left.\mathrm{NO}_{3}^{-}\right)$also present correlations with major cations and are correlated with each other. They are also correlated with EC suggesting that anions' concomitant input enhances cations released into groundwater. However, $\mathrm{Cl}^{-}$and $\mathrm{SO}_{4}^{2-}$ showed no correlation with $\mathrm{HCO}_{3}^{-}$. Both neutral ions could then be considered as exogenous or as indicators of

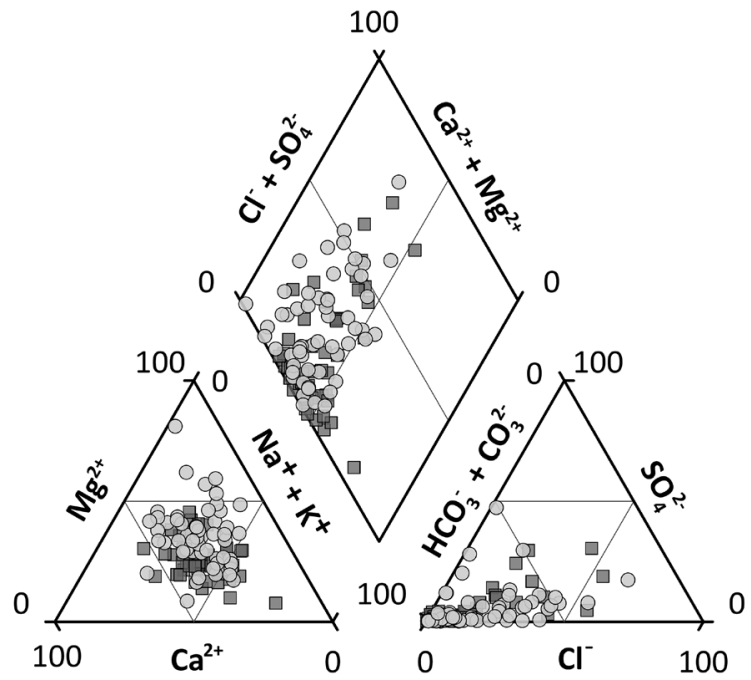

Figure 3. Piper diagram showing hydrochemical facies of groundwater samples for the two sampling years 2011 (square markers) and 2014 (circle markers). 
Table 2. Spearman rank-order correlation coefficients statistically significant at $\mathrm{p}<0.050$.

\begin{tabular}{|c|c|c|c|c|c|c|c|c|c|}
\hline & $\mathrm{pH}$ & EC & $\mathrm{Ca}^{2+}$ & $\mathrm{Mg}^{2+}$ & $\mathrm{Na}^{+}$ & $\mathrm{K}^{+}$ & $\mathrm{HCO}_{3}^{-}$ & $\mathrm{Cl}^{-}$ & $\mathrm{SO}_{4}^{2-}$ \\
\hline \multicolumn{10}{|l|}{$\mathrm{pH}$} \\
\hline EC & 0.23 & & & & & & & & \\
\hline $\mathrm{Ca}^{2+}$ & & 0.74 & & & & & & & \\
\hline $\mathrm{Mg}^{2+}$ & 0.24 & 0.80 & 0.48 & & & & & & \\
\hline $\mathrm{Na}^{+}$ & 0.27 & 0.81 & 0.56 & 0.47 & & & & & \\
\hline $\mathrm{K}^{+}$ & & 0.62 & 0.49 & 0.48 & 0.59 & & & & \\
\hline $\mathrm{HCO}_{3}^{-}$ & 0.59 & 0.51 & 0.38 & 0.49 & 0.47 & 0.35 & & & \\
\hline $\mathrm{Cl}^{-}$ & & 0.67 & 0.58 & 0.52 & 0.56 & 0.42 & & & \\
\hline $\mathrm{SO}_{4}^{2-}$ & & 0.69 & 0.56 & 0.50 & 0.61 & 0.58 & & 0.59 & \\
\hline $\mathrm{NO}_{3}^{-}$ & -0.27 & 0.42 & 0.38 & 0.33 & 0.25 & & -0.31 & 0.65 & 0.48 \\
\hline
\end{tabular}

anthropogenic influence [29] [32]. Nitrate shows a weak but significant negative correlation with $\mathrm{HCO}_{3}^{-}$and $\mathrm{pH}$ revealing the antagonist effect between the evolution of nitrate and alkalinity in groundwater. The increase of nitrate through acidifying processes such as nitrification and organic matter decomposition can decrease groundwater alkalinity, while denitrification is an alkalinity generation process [4].

\subsection{Factors Controlling Groundwater Geochemistry}

The results of R-mode factor analysis are presented in Table 3. Only variables with extracted communalities equal to or higher than 0.5 were considered for the factor analysis [33]. The variables such as $\mathrm{pH}$ and $\mathrm{K}^{+}$with communalities below the set lower limit were discarded. TDS was excluded from the factor analysis to avoid the redundancy effect with EC.

Based on the Kaiser criterion, only the first two factors with eigenvalues greater than one were retained. They account for $76.5 \%$ of the variance in the hydrochemical dataset (Table 3). The first factor explains $57.4 \%$ of the total variance and has high positive loadings $(>0.70)$ for $\mathrm{EC}, \mathrm{Ca}^{2+}, \mathrm{Mg}^{2+} \mathrm{Na}^{+}$, and $\mathrm{HCO}_{3}^{-}$. The second factor accounts for $19.1 \%$ of the total variance and is characterized by high and positive loadings $(>0.70)$ for $\mathrm{NO}_{3}^{-}$and $\mathrm{Cl}^{-}$, moderate positive loading $(>0.5)$ for $\mathrm{SO}_{4}^{2-}$. Factor 1 is defined as a natural component characterized by the weathering of silicates minerals due to crystalline basement rocks underlying the study area, the higher concentrations of silica, and the inter-ionic relationship discussed above in section 4.2. Factor 2 is appointed as an anthropogenic component characterized by indicators of the influence of agriculture and pastoral activities and domestic waste in residential areas. The chemical fertilizers (NPK and NPKSB) application [8] [20] [21], the extensive use of pesticides [34], manure from pastoral and transhumance activities [9], 
Table 3. Factor analysis results using principal components extraction and Varimax normalized rotation methods.

\begin{tabular}{ccccc}
\hline \multirow{2}{*}{ Variables } & \multicolumn{2}{c}{ Communalities } & \multicolumn{2}{c}{ Factors } \\
\cline { 2 - 5 } & Initial & Extracted & 1 & 2 \\
\hline $\mathrm{EC}$ & 1.00 & 0.95 & 0.85 & 0.48 \\
$\mathrm{Ca}^{2+}$ & 1.00 & 0.76 & 0.72 & 0.44 \\
$\mathrm{Mg}^{2+}$ & 1.00 & 0.84 & 0.75 & 0.33 \\
$\mathrm{Na}^{+}$ & 1.00 & 0.78 & 0.75 & 0.29 \\
$\mathrm{HCO}_{3}^{-}$ & 1.00 & 0.72 & 0.88 & -0.36 \\
$\mathrm{Cl}^{-}$ & 1.00 & 0.63 & 0.35 & 0.80 \\
$\mathrm{SO}_{4}^{2-}$ & 1.00 & 0.55 & 0.49 & 0.61 \\
$\mathrm{NO}_{3}^{-}$ & 1.00 & 0.60 & 0.00 & 0.91 \\
& Eigenvalue & & 4.6 & 1.5 \\
\% of variance explained by the factor & 57.4 & 19.1 \\
& Cumulative \% of the variance & 57.4 & 76.5 \\
\hline
\end{tabular}

and human wastes generation from residential areas around boreholes appear as the probable sources of anthropogenic nitrate, chloride and sulfate contents in groundwater from the study area. The negative correlation evidenced previously between the evolution of nitrate and alkalinity in groundwater (Table 2) is corroborated by a week but negative and significant loading of $\mathrm{HCO}_{3}^{-}$for Factor 2 .

The conjunct control of silicates minerals weathering and anthropogenic pollution on groundwater's hydrogeochemical evolution was also reported from other studies in basement areas. They have mentioned a relationship between nitrate pollution and the increase in groundwater salinization [19] [33] [35]. A study including five (5) different aquifer types in NE Spain reported a significant difference in groundwater salinization when groundwater in igneous and sedimentary aquifers is compared under natural conditions while these differences are reduced and become insignificant under high nitrate pollution [19]. This Nitrate-salinization relationship contrasts with studies in the weathered basement aquifers in Northern Malawi, which revealed an increase of salinity due to evaporation processes and saline water's intrusion nearby sedimentary aquifers through fault and fracture zones [2] [19]. Investigations on salinization of basement aquifers in France and India showed that high evaporation rates and irrigation return flow, or mixing with a saline fossil water, result in groundwater salinization [6]. It appears natural and/or anthropogenic processes control on salinization of groundwater from basement aquifer systems. The influence of anthropogenic induced salinity should be considered in areas with prevailing fresh groundwater for the resource's sustainability. The distinction between the contribution of both processes should be considered in areas with prevailing saline 
groundwater in other to improve groundwater resources development, exploitation, and management [7] [8] [21].

\subsection{Hydrochemical Families}

The Q-mode hierarchical cluster analysis results are presented as a dendrogram (Figure 4(a)) where four clusters (C1, C2, C3, and C4) are selected subjectively based on visual examination. The median concentrations of chemical constituents in each group are presented in Table 4. The Stiff diagrams of the median hydrochemical facies of the selected clusters are shown in Figure 4(b). The variation of the partial pressure of $\mathrm{CO}_{2}$ gas and the factorial scores are presented in Figure 4(c) and Figure 4(d), respectively. The first cluster (C1) recorded the highest TDS and ionic concentrations but with a lower median concentration of silica compared to other groups (Table 4). The proportions of ions $\left(\mathrm{Na}^{+}, \mathrm{K}^{+}, \mathrm{Cl}^{-}\right.$ and $\mathrm{SO}_{4}^{2-}$ ), which are ubiquitous in a saline environment, are substantially higher in this cluster. Its median composition is characterized by $\mathrm{Na}-\mathrm{HCO}_{3}-\mathrm{Cl}$ water type in the Stiff diagram (Figure 4(b)). Most of the C1 samples are located in the Central toward the Southeastern part of the study area, where ground elevations are relatively low (Figure 5(a)). In contrast, Cluster 3 is composed of samples with the lowest median concentrations of ions and TDS (Table 4) exhibiting $\mathrm{Na}-\mathrm{HCO}_{3}$ water type (Figure $4(\mathrm{~b})$ ) and the highest partial pressure of
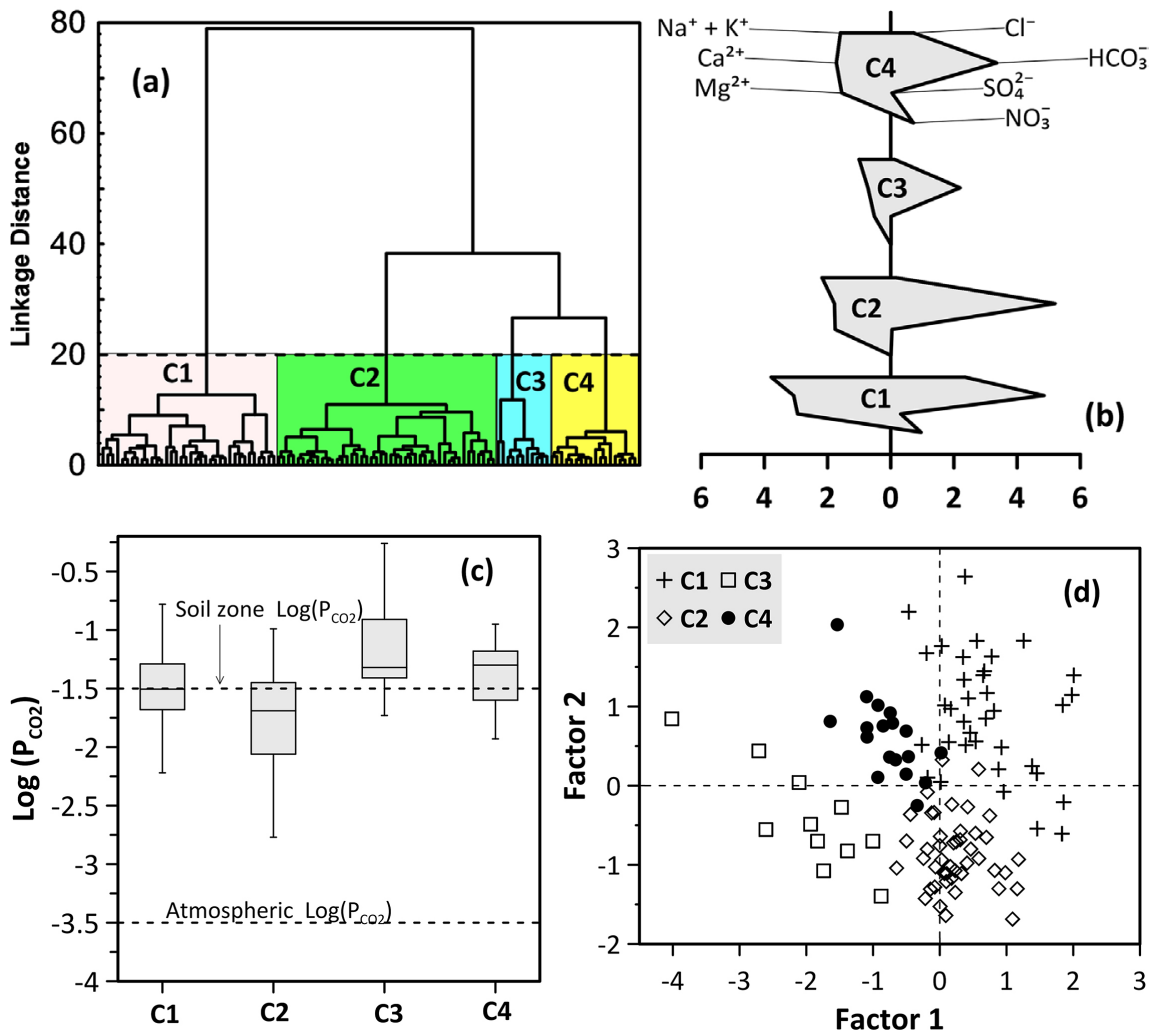

Figure 4. (a) Dendrogram from HCA, (b) Stiff diagram of the median concentration of each cluster, (c) Variation of $\mathrm{CO}_{2}$ gas partial pressure in different clusters, (d) Factorials scores recorded in different clusters. 
Table 4. Median chemical composition of groundwater in each cluster.

\begin{tabular}{cccccccccccccc}
\hline \multirow{2}{*}{ Variables } & $\begin{array}{c}\mathrm{pH} \\
(-)\end{array}$ & $\begin{array}{c}\mathrm{EC} \\
(\mu \mathrm{S} / \mathrm{cm})\end{array}$ & $\begin{array}{c}\mathrm{TDS} \\
(\mathrm{mg} / \mathrm{L})\end{array}$ & $\begin{array}{c}\mathrm{Ca}^{2+} \\
(\mathrm{mg} / \mathrm{L})\end{array}$ & $\begin{array}{c}\mathrm{Mg}^{2+} \\
(\mathrm{mg} / \mathrm{L})\end{array}$ & $\begin{array}{c}\mathrm{Na}^{+} \\
(\mathrm{mg} / \mathrm{L})\end{array}$ & $\begin{array}{c}\mathrm{K}^{+} \\
(\mathrm{mg} / \mathrm{L})\end{array}$ & $\begin{array}{c}\mathrm{HCO}_{3}^{-} \\
(\mathrm{mg} / \mathrm{L})\end{array}$ & $\begin{array}{c}\mathrm{Cl}^{-} \\
(\mathrm{mg} / \mathrm{L})\end{array}$ & $\begin{array}{c}\mathrm{SO}_{4}^{2-} \\
(\mathrm{mg} / \mathrm{L})\end{array}$ & $\begin{array}{c}\mathrm{NO}_{3}^{-} \\
(\mathrm{mg} / \mathrm{L})\end{array}$ & $\begin{array}{c}\mathrm{SiO}_{2} \\
(\mathrm{mg} / \mathrm{L})\end{array}$ \\
\hline \multirow{6}{*}{ Clusters } & $\mathrm{C} 1$ & 7.0 & 954 & 723 & 61.4 & 35.4 & 82.5 & 7.7 & 295.9 & 83.6 & 30.2 & 58.6 & 49.8 \\
& $\mathrm{C} 2$ & 7.3 & 500 & 358 & 35.6 & 21.1 & 46.6 & 5.7 & 317.2 & 6.0 & 3.8 & 0.5 & 51.5 \\
& $\mathrm{C} 3$ & 6.5 & 211 & 162 & 14.4 & 6.2 & 21.1 & 3.2 & 134.0 & 4.0 & 1.0 & 0.6 & 34.8 \\
& $\mathrm{C} 4$ & 6.6 & 447 & 320 & 34.4 & 18.6 & 34.0 & 4.4 & 204.4 & 25.5 & 3.7 & 43.9 & 62.1 \\
\hline
\end{tabular}

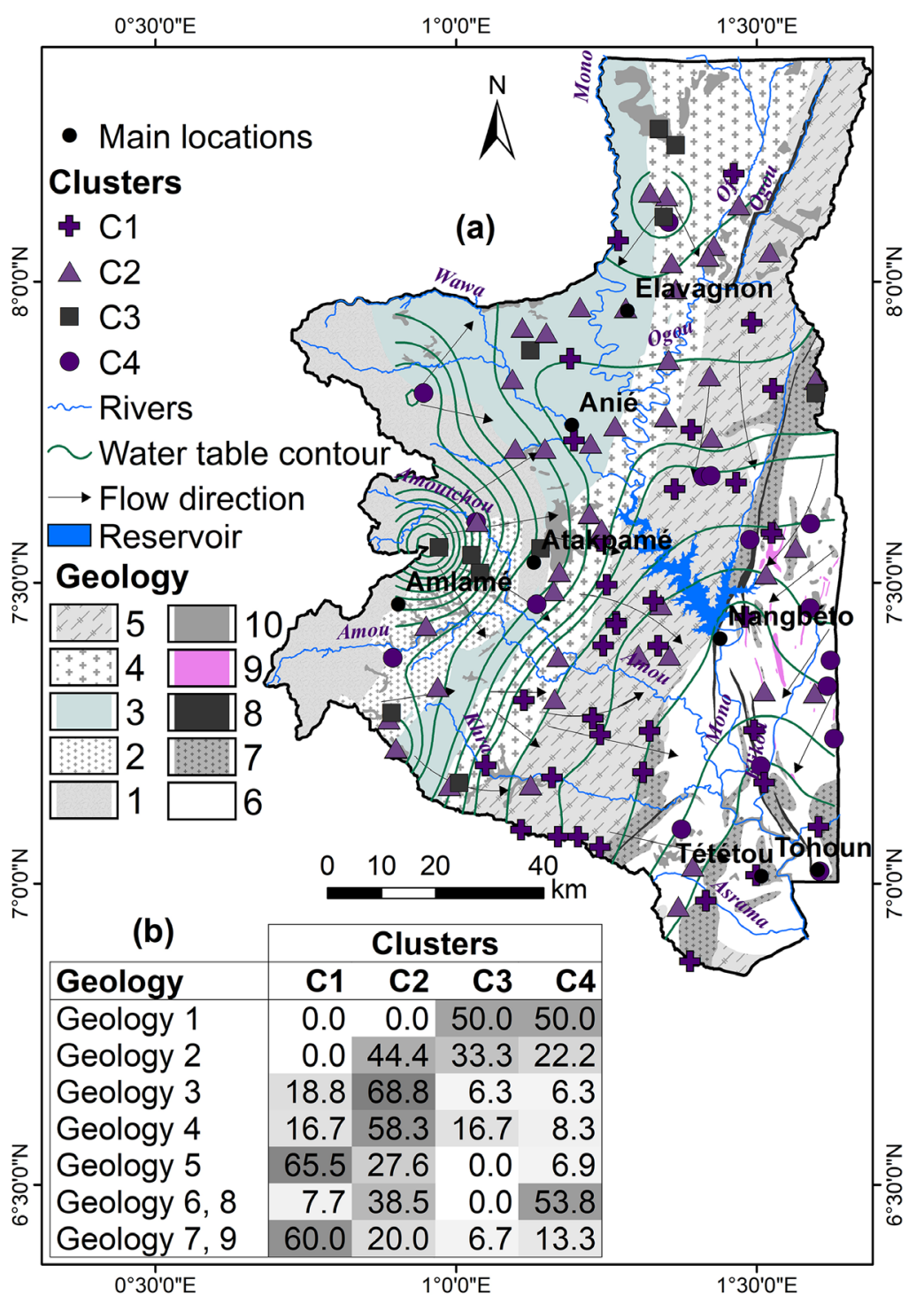

Figure 5. (a) Spatial distribution of clusters from Q-mode HCA and (b) Heatmap showing the percentage of hydrochemical families (Cluster) recorded in each geological unit. The total rate is equal to $100 \%$ in each geological unit (on each line). The water level is calculated by subtracting the depth to the water table measured in 2014 from the elevation extracted from SRTM data [36]. Water level contour is obtained, applying the inverse distance to a power smoothing interpolator to water level data. (For geology interpretation, please see Figure 1). 
$\mathrm{CO}_{2}$ (Figure 4(c)). Most of the samples are located in higher elevations areas in the North and the West of the study area (Figure 5(a)). Clusters 2 and 4 samples present intermediate mineralization levels and are scattered between Clusters 3 and 1 samples (Figure 5(a)). However, Cluster 4, mostly represented in the Eastern part, presents higher median concentrations of $\mathrm{NO}_{3}^{-}$and $\mathrm{SiO}_{2}(\mathrm{Table}$ 4) than Cluster 2, where samples recorded the lowest partial pressure of $\mathrm{CO}_{2}$ (Figure $4(\mathrm{c})$ ). Both clusters are characterized by $\mathrm{Ca}-\mathrm{HCO}_{3}$ and $\mathrm{Na}-\mathrm{HCO}_{3}$ water types, respectively (Figure $4(\mathrm{~b})$ ).

The pattern of the spatial distribution of clusters (Figure 5(a)) showing an increase of groundwater mineralization along flow direction from highland (Clusters 3 and 4) toward low elevation (Cluster 1 and 2) locations suggest topographically-driven groundwater flow through the fractures network [28] [33]. However, additional analyses are required to test hydraulic fracture connectivity and groundwater circulation patterns. Further, the proximity of samples belonging to different clusters suggests other factors' influence and corroborates natural and anthropogenic impacts. Figure 4(d) shows that Cluster 3 recorded low scores for both Factors 1 and 2, indicating short-term water-rock interactions and low or negligible influence of anthropogenic related processes. The factorial scores for Cluster 4 are also weak for Factor 1 but high for Factor 2, indicating an anthropogenic impact. The increased partial pressure of $\mathrm{CO}_{2}$ gas characteristic of soil zone in the low mineralized samples (Clusters 3 and 4) means infiltrating water enriched with soil $\mathrm{CO}_{2}$ gas [4] [28]. This suggests a modification of rainwater chemistry by geochemical processes in the soil zone at an early stage of hydrochemical evolution during recharge [4]. Cluster 2 recorded low scores for Factor 2 and higher scores for Factor 1 (Figure 4(d)), high mineralization (Table 4), and lower partial pressure of $\mathrm{CO}_{2}$ gas (Figure 4(c)). It reflects a progressive hydrochemical evolution with increased control of minerals weathering through $\mathrm{CO}_{2}$ gas consumption along the groundwater flow path [4]. The scores of Factors 1 and 2 are high for Cluster 1, indicating the impact of natural and anthropogenic factors. This cluster presents relatively high partial pressure of $\mathrm{CO}_{2}$ gas (Figure 4(c)), exhibiting a hydrochemical evolution under open conditions.

The relationship between clusters and geological settings (Figure 5(b)) shows that: the Atacora structural unit (Geology 1) is characterized by Clusters 3 and 4 , the Amlamé Kpalimé granitoïds (Geology 2) by Clusters 2 and 3 and somewhat cluster 4, the suture zone (geology 3) and central granitic gneiss by (Geology 4) Cluster 2, the central migmatites (Geology 5) and the oriental granitoïds (Geology 7 and 9) by Cluster 1 and the oriental dioritic gneiss (Geology 6 and 8) by Clusters 2 and 4. It appears that the central migmatites and the oriental dioritic gneiss and granitoids zones appear more vulnerable to anthropogenic influence and groundwater salinization. In the Central and Eastern parts of the study area, lower elevation with depressure, flat and gentle slopes, deforestation, semi-arid conditions, intensive agriculture, and pasture systems may favor the formation 
of soil crusts [21] [35] [37] [38]. Furthermore, solutes could be transferred quickly into groundwater due to the relatively sandy weathering profile and thickness [21] [29]. Inversely, the higher rainfall and clayey weathering profile conditions in the West represent limiting factors for groundwater salinization [20].

\subsection{Mechanisms and Processes of Groundwater Salinization}

The controls of rainwater chemistry, water-rock interactions, and evaporationprecipitation processes on groundwater chemistry evolution were distinguished using the Gibbs diagram. The plots of TDS versus the relative cationic fraction $\left[\mathrm{Na}^{+} /\left(\mathrm{Ca}^{2+}+\mathrm{Na}^{+}\right)\right]$and anionic fraction $\left[\mathrm{Cl}^{-} /\left(\mathrm{HCO}_{3}^{-}+\mathrm{Cl}^{-}\right)\right]$(Figure 6) show that minerals weathering through water rock-interactions is the dominant mechanism controlling groundwater chemistry in the study area. Some samples in Cluster 3 are probably affected by the control of rainwater chemistry, indicating a high groundwater renewal rate from rainfall infiltration or slow kinetic of minerals weathering. Samples in Cluster 1 with relatively higher salinity reflect the influence of evaporation and the precipitation of secondary minerals phases.

In the plot of $\left(\mathrm{Ca}^{2+}+\mathrm{Mg}^{2+}\right)$ vs. $\mathrm{HCO}_{3}^{-}$(Figure $\left.7(\mathrm{a})\right)$, most of the points deviated from the 1:1 line indicating a substantial contribution of alkaline cations neutral acid anions to groundwater chemistry. The plot of Total cations versus $\mathrm{HCO}_{3}^{-}$(Figure 7(b)) shows that Clusters 2 and 3 fall along the 1:1 line, indicating the weathering of a range of silicate minerals such as plagioclase, biotite, alkaline-feldspar, amphiboles, and pyroxenes [29] [35]. The molar ratio $\mathrm{HCO}_{3}^{-} / \mathrm{SiO}_{2}$ is expected to be lower than 5 for dominant silicate weathering and higher than 10 for carbonates minerals dissolution since silica is not released by dissolving carbonate [39]. The $\mathrm{HCO}_{3}^{-} / \mathrm{SiO}_{2}$ ratio varied from 1.9 to 17.2 with a median value of 5.4 and a mean value of 6.1 , suggesting that silicate minerals have great
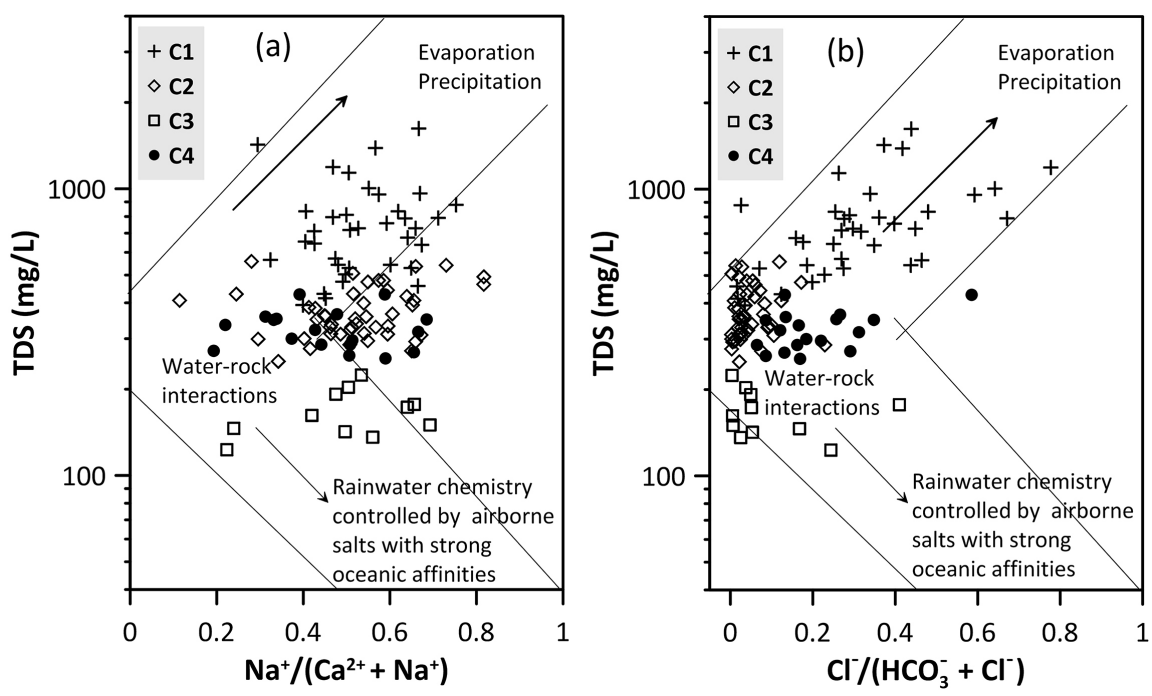

Figure 6. Gibbs Diagramms (a) TDS $v s\left[\mathrm{Na}^{+} /\left(\mathrm{Ca}^{2+}+\mathrm{Na}^{+}\right)\right]$and (b) TDS $v s\left[\mathrm{Cl}^{-} /\left(\mathrm{HCO}_{3}^{-}\right.\right.$ $\left.\left.+\mathrm{Cl}^{-}\right)\right]$. 
control on groundwater chemistry's natural evolution from early to an advanced stage in the study area. The water-rock interactions dominance as the primary geochemical mechanism supports the hypothesis of carbonic acid-driven hydrolysis of silicate minerals according to Equations (1) to (6) [4]. However, samples from Clusters 1 and 4 shifted above the 1:1 line in Figure 7(b). The excess of cations balance with $\mathrm{Cl}^{-}, \mathrm{SO}_{4}^{2-}$ and $\mathrm{NO}_{3}^{-}$from probably anthropogenic sources.

$$
\begin{aligned}
& \mathrm{CaAl}_{2} \mathrm{Si}_{2} \mathrm{O}_{8 \text { anorthite }}+3 \mathrm{H}_{2} \mathrm{O}+2 \mathrm{CO}_{2(\mathrm{~g})} \\
& \rightarrow \mathrm{Ca}^{2+}+2 \mathrm{HCO}_{3}^{-}+\mathrm{Al}_{2} \mathrm{Si}_{2} \mathrm{O}_{5}(\mathrm{OH})_{4 \text { kaolinite }} \\
& 2 \mathrm{NaAlSi}_{3} \mathrm{O}_{8 \text { albite }}+20 \mathrm{H}_{2} \mathrm{O}+2 \mathrm{CO}_{2(\mathrm{~g})} \\
& \rightarrow \mathrm{Na}^{+}+2 \mathrm{HCO}_{3}^{-}+4 \mathrm{H}_{4} \mathrm{SiO}_{4}+\mathrm{Al}_{2} \mathrm{Si}_{2} \mathrm{O}_{5}(\mathrm{OH})_{4 \text { kaolinite }} \\
& 2 \mathrm{KAlSi}_{3} \mathrm{O}_{8 \mathrm{~K} \text {-feldspar }}+20 \mathrm{H}_{2} \mathrm{O}+2 \mathrm{CO}_{2(\mathrm{~g})} \\
& \rightarrow \mathrm{K}^{+}+2 \mathrm{HCO}_{3}^{-}+4 \mathrm{H}_{4} \mathrm{SiO}_{4}+\mathrm{Al}_{2} \mathrm{Si}_{2} \mathrm{O}_{5}(\mathrm{OH})_{4 \text { kaolinite }} \\
& 2 \mathrm{KMg}_{3} \mathrm{AlSi}_{3} \mathrm{O}_{10}(\mathrm{OH})_{2 \text { biotite }}+15 \mathrm{H}_{2} \mathrm{O}+14 \mathrm{CO}_{2(\mathrm{~g})} \\
& \rightarrow 2 \mathrm{~K}^{+}+6 \mathrm{Mg}^{2+}+14 \mathrm{HCO}_{3}^{-}+4 \mathrm{H}_{4} \mathrm{SiO}_{4}+\mathrm{Al}_{2} \mathrm{Si}_{2} \mathrm{O}_{5}(\mathrm{OH})_{4 \text { kaolinite }} \\
& \mathrm{CaMgSi}_{2} \mathrm{O}_{6 \text { pyroxène }}+6 \mathrm{H}_{2} \mathrm{O}+4 \mathrm{CO}_{2(\mathrm{~g})} \\
& \rightarrow \mathrm{Ca}^{2+}+\mathrm{Mg}^{2+}+4 \mathrm{HCO}_{3}^{-}+2 \mathrm{H}_{4} \mathrm{SiO}_{4} \\
& \mathrm{Ca}_{2} \mathrm{Mg}_{5} \mathrm{Si}_{8} \mathrm{O}_{22}\left(\mathrm{OH}_{2}\right)_{\text {amphibole }}+22 \mathrm{H}_{2} \mathrm{O}+14 \mathrm{CO}_{2(\mathrm{~g})} \\
& \rightarrow 2 \mathrm{Ca}^{2+}+5 \mathrm{Mg}^{2+}+14 \mathrm{HCO}_{3}^{-}+8 \mathrm{H}_{4} \mathrm{SiO}_{4}
\end{aligned}
$$

The molar ratio $\mathrm{NO}_{3}^{-} / \mathrm{Cl}^{-}$of around 1 for samples with a high content of $\mathrm{NO}_{3}^{-}$indicates that animal and human wastes are the primary sources of contamination (Figure $7(\mathrm{c})$ ). In contrast, a higher ratio in few samples reveals that contamination from fertilizers and vegetation in agriculture is less prominent [32]. The increase of halite saturation indices with $\mathrm{NO}_{3}^{-}$(Figure $7(d)$ ) supports salinity enhancement by nitrate contamination. $\mathrm{NO}_{3}^{-}$is reactive contrary to $\mathrm{Cl}^{-}$which is conservative, and also nitrate can oxidize sulfur into sulfate. Thus, the decrease of $\mathrm{NO}_{3}^{-} / \mathrm{Cl}^{-}$ratio, and $\mathrm{NO}_{3}^{-}$content while groundwater salinity remains high for some samples in Cluster 1 indicates that nitrate reduction occurs through denitrification processes. The contribution of denitrification to $\mathrm{SO}_{4}^{2-}$ in groundwater is conceivable from Figure $7(\mathrm{e})$ where the saturation indice of gypsum increases with $\mathrm{SO}_{4}^{2-}$ concentration while nitrate concentration decreases. Sulfide minerals such as pyrite $\left(\mathrm{FeS}_{2}\right)$ often present in basement rocks are typically expected to reduce $\mathrm{NO}_{3}^{-}$as illustrated by Equation (7) [4] [6].

$$
5 \mathrm{FeS}_{2}+14 \mathrm{NO}_{3}^{-}+4 \mathrm{H}^{+} \rightarrow 7 \mathrm{~N}_{2}+10 \mathrm{SO}_{4}^{2-}+5 \mathrm{Fe}^{2+}+2 \mathrm{H}_{2} \mathrm{O}
$$

Although denitrification could occur, the positive and significant correlation $(\mathrm{r}=0.48 ; \mathrm{p}<0.05)$ between $\mathrm{NO}_{3}^{-}$and $\mathrm{SO}_{4}^{2-} \quad($ Table 2$)$ suggests that its control on the content of $\mathrm{SO}_{4}^{2-}$ is limited to few samples or is superimposed by the trend of concomitant increase of $\mathrm{SO}_{4}^{2-}$ and $\mathrm{NO}_{3}^{-}$contaminations from NPKSB fertilizers, manure, and domestic wastes. 

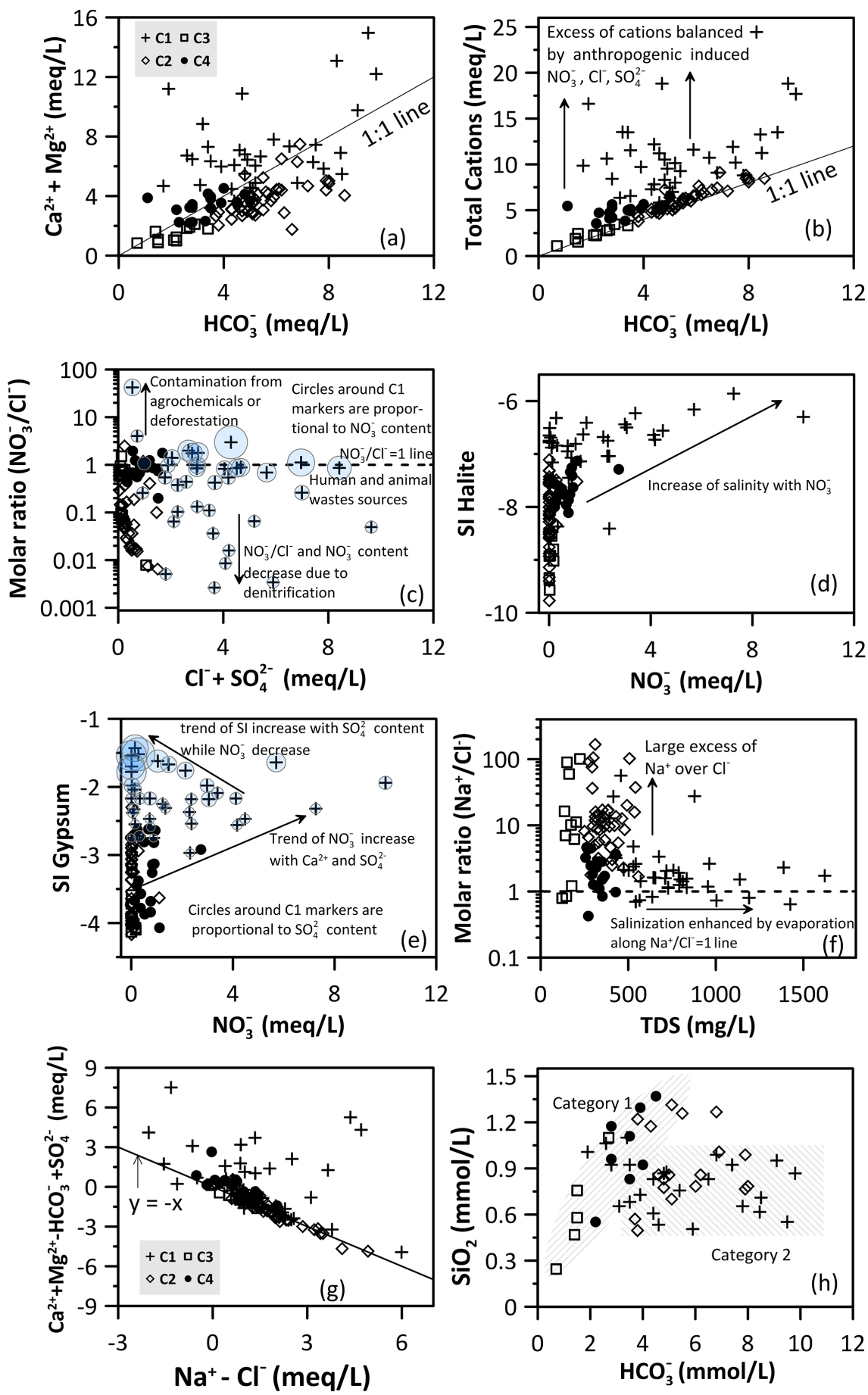

Figure 7. Bivariate plots of (a) $\left(\mathrm{Ca}^{2+}+\mathrm{Mg}^{2+}\right)$ vs $\mathrm{HCO}_{3}^{-}$; (b) Total Cations vs $\mathrm{HCO}_{3}^{-}$, (c) Molar ratio $\left(\mathrm{NO}_{3}^{-} / \mathrm{Cl}^{-}\right) v s\left(\mathrm{Cl}^{-}+\mathrm{SO}_{4}^{2-}\right)$; (d) SI Halite vs $\mathrm{NO}_{3}^{-}$; (e) SI Gypsum $v s \mathrm{NO}_{3}^{-}$ (f) Molar ratio $\left(\mathrm{Na}^{+} / \mathrm{Cl}^{-}\right)$vs TDS; (g) $\left(\mathrm{Ca}^{2+}+\mathrm{Mg}^{2+}-\mathrm{HCO}_{3}^{-}-\mathrm{SO}_{4}^{2-}\right) v s\left(\mathrm{Na}^{+}-\mathrm{Cl}^{-}\right)$and (h) $\mathrm{SiO}_{2}$ vs $\mathrm{HCO}_{3}^{-}$.

Groundwater salinization could be magnified by evaporation processes as suspected above (Figure 6). Epavoration or evapotranspiration favors $\mathrm{Na}^{+}$and $\mathrm{Cl}^{-}$increase while calcite and dolomite precipitate [40]. Hence, the molar ratio 
$\mathrm{Na}^{+} / \mathrm{Cl}$ remains constant, while TDS increase [40] [41] [42]. Accordingly, the contribution of evaporation to groundwater salinization in the study area, which is not a coastal area, is evidenced by the fact that most samples in Cluster 2 fall nearly along with the molar ratio $\mathrm{Na}^{+} / \mathrm{Cl}^{+}=1$ line (Figure $7(\mathrm{f})$ ) and present saturation to oversaturation with respect to calcite and dolomite (Figure 8(b)). The higher $\mathrm{Na}^{+} / \mathrm{Cl}^{-}$ratio than 1 suggests additional sources such as silicates weathering or cation exchange. The study area is considered favorable for the cationic exchange processes due to clay minerals, which are the weathering product of silicate minerals in the aquifer matrix. The ion exchange and reverse ion exchange of cations between aqueous and solid phases can be explained by the following reaction in the direct or inverse sens, respectively [42].

$$
2 \mathrm{Na}^{+}+\mathrm{Ca}(\mathrm{Mg}) \text { Clay } \leftrightarrow \mathrm{Na} \text { Clay }+\mathrm{Ca}^{2+}\left(\mathrm{Mg}^{2+}\right)
$$

In the plot of $\left(\mathrm{Ca}^{2+}+\mathrm{Mg}^{2+}-\mathrm{HCO}_{3}^{-}+\mathrm{SO}_{4}^{2-}\right)$ versus $\left(\mathrm{Na}^{+}-\mathrm{Cl}^{-}\right)$(Figure $7(\mathrm{~g})$ ), the cation exchange process is supported by the points falling along a line with a slope of $-1(y=-x)$ showing an inversely proportional change between $\mathrm{Na}^{+}$and $\mathrm{Ca}^{2+}$ and/or $\mathrm{Mg}^{2+}$ content in groundwater [17] [29] [42].

The above results show that silicate weathering and cation exchange processes increase $\mathrm{Na}^{+}$release into groundwater, while $\mathrm{Cl}^{-}$and $\mathrm{SO}_{4}^{2-} \mathrm{NO}_{3}^{-}$originate from similar anthropogenic sources. $\mathrm{Na}^{+}, \mathrm{Cl}^{-}$and probably $\mathrm{SO}_{4}^{2-}$ content are magnified by evaporation. The impact of groundwater salinization on silicate weathering is assessed using the plot of $\mathrm{SiO}_{2}$ versus $\mathrm{HCO}_{3}^{-}$(Figure $7(\mathrm{~h})$ ). There is a concomitant increase of silica and bicarbonate at low mineralization/salinization level (Category 1). This strong correlation indicates the same sources as the acidic hydrolysis of silicates minerals (Equations (1) to (6)). At a higher mineralization level (Category 2), the silica content range becomes narrow without a visible relationship. Figure 8 shows that all samples are saturated and oversaturated with respect to quartz, chalcedony, and amorphous silica $(-0.5<\mathrm{SI}<+0.5)$, indicating thermodynamic equilibrium conditions silica or silicates are prone to deposition. Moreover, samples in Category 1 (Clusters 3 and 4) are undersaturated with respect to sepiolite and talc. In contrast, most of the samples in Category 2 recorded the lowest partial pressure of $\mathrm{CO}_{2}$ gas (Figure 4(c)), highest median values of $\mathrm{pH}$ (Table 4), and are saturated to oversaturated with respect to calcite, dolomite, sepiolite, and talc (Figure 8(a) and Figure $8(\mathrm{~b})$ ). Thus, the acidic hydrolysis of primary silicate minerals becomes difficult or prohibited from a certain mineralization stage. $\mathrm{CO}_{2}$ gas can dissolve into $\mathrm{HCO}_{3}^{-}$due to groundwater equilibrium with calcite and dolomite [4]. That is why samples in both Cluster 1 and 2 present high $\mathrm{HCO}_{3}^{-}$over silica content apart from the anthropogenic impact. However, the extent of primary silicate weathering, the silica content in groundwater, and neoformed silicates depend on the hydrodynamic and hydraulic conditions of the aquifer system [3] [16] [43]. This may explain why few samples from Category 2 (Clusters 1 and 2) fall in the domain of Category 1 (Clusters 3 and 4) (Figure 7(h)). 

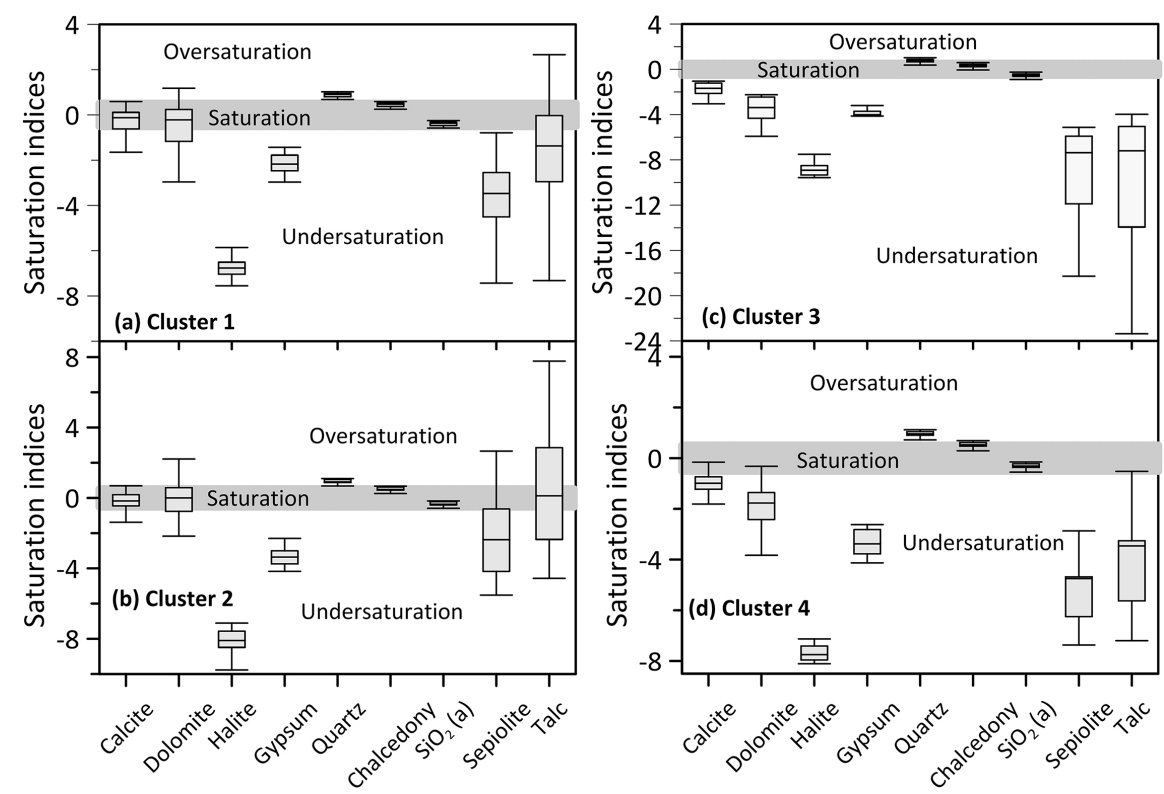

Figure 8. Box plot of saturation indices for the Cluster.

\section{Conclusion}

The relative influence of natural and anthropogenic factors on groundwater salinization in the middle part of Mono River Bassin in Togo was assessed in this study. Groundwater is generally fresh with mixed cations $-\mathrm{HCO}_{3}$ as dominant hydrochemical facies. However, salinization increases substantially with TDS and nitrate contamination. Few hydrochemical parameters showed an interannual variation due to coincidental or seasonal variations of geochemical processes related to local hydrogeological settings' heterogeneity. The factor analysis derived two factors, which are defined as the natural component characterized by minerals weathering and the anthropogenic component characterized by chemical indicators of agriculture and residential pollution. Both factors explained $76.5 \%$ of the total variance in the hydrochemical dataset. Based on the HCA, groundwater samples were classified into 4 clusters illustrating different stages of hydrochemical evolution. The examination of the statistical results with spatial analysis and conventional diagrams allows distinguishing the geochemical behavior of the hydrochemical families. The primary natural process is the weathering of silicate minerals and possibly secondary carbonates by infiltrating water enriched with soil $\mathrm{CO}_{2}$ gas through the water-rock interaction mechanism. Other processes include cation exchange on the clayey aquifer matrix and the precipitation of minerals such as calcite, dolomite along the flow path. The anthropogenic inputs are derived from potential sources, including human and animal wastes, agrochemicals, and deforestation. The findings align with the central hypothesis, suggesting that groundwater salinization proceeds from anthropogenic sources and related processes. It is shown that evaporation magnifies the groundwater salinization process in the lower elevation areas, particularly toward depressions in the central part of the study area, where the formation of soil crusts is favorable. The 
release of silica into groundwater through acidic hydrolysis of silicates decreases or becomes prohibited at the expense of lowering $\mathrm{CO}_{2}$ gas partial pressure and groundwater saturation to oversaturation with respect to secondary carbonate and silicates minerals. This study showed the effective use of multivariate statistical analysis and conventional hydrochemical techniques in identifying the primary factors and processes controlling groundwater chemistry.

\section{Acknowledgements}

The authors are thankful to PIMASO Programme under the Intra-Africa Academic Mobility Scheme financed by the European Union and the UNESCO/Keizo Obuchi Research Fellowships Programme for supporting the research activities of the first author. We wish to thank the Water Resource of Board of Togo for providing boreholes data.

\section{Conflicts of Interest}

The authors declare no conflicts of interest regarding the publication of this paper.

\section{References}

[1] Güler, C. and Thyne, G.D. (2004) Hydrologic and Geologic Factors Controlling Surface and Groundwater Chemistry in Indian Wells-Owens Valley Area, Southeastern California, USA. Journal of Hydrology, 285, 177-198.

https://doi.org/10.1016/j.jhydrol.2003.08.019

[2] Monjerezi, M., Vogt, R.D., Aagaard, P. and Saka, J.D.K. (2012) The Hydro-Geochemistry of Groundwater Resources in an Area with Prevailing Saline Groundwater, Lower Shire Valley, Malawi. Journal of African Earth Sciences, 68, 67-81. https://doi.org/10.1016/j.jafrearsci.2012.03.012

[3] Yidana, S.M., Dzikunoo, E.A., Aliou, A.-S., Adams, R.M., Chagbeleh, L.P. and Anani, C. (2020) The Geological and Hydrogeological Framework of the Panabako, Kodjari, and Bimbilla Formations of the Voltaian Supergroup-Revelations from Groundwater Hydrochemical Data. Applied Geochemistry, 115, Article ID: 104533. https://doi.org/10.1016/j.apgeochem.2020.104533

[4] Appelo, C.A.J. and Postma, D. (2005) Geochemistry, Groundwater and Pollution. 2nd Edition, CRC Press, Taylor \& Francis Group, Boca Raton. https://doi.org/10.1201/9781439833544

[5] Liu, F., et al. (2015) The Role of Anthropogenic and Natural Factors in Shaping the Geochemical Evolution of Groundwater in the Subei Lake Basin, Ordos Energy Base, Northwestern China. Science of the Total Environment, 538, 327-340. https://doi.org/10.1016/j.scitotenv.2015.08.057

[6] Pauwels, H., Aquilina, L., Negrel, P., Bour, O., Perrin, J. and Ahmed, S. (2013) Groundwater Salinization in Hard-Rock Aquifers: Impact of Pumping and Vertical Transfers. Procedia Earth and Planetary Science, 7, 660-664. https://doi.org/10.1016/j.proeps.2013.03.189

[7] Amoussou, E. (2010) Variabilité pluviométrique et dynamique hydro-sédimentaire du bassin-versant du complexe fluvio-lagunaire Mono-Ahémé-Couffo (Afrique de l'Ouest). Thèse de Doctorat, Université de Bourgogne (France).

[8] Oladokoun, W. (2000) Dimension sociale et économique de la culture cotonnière au 
Togo: L'exemple de l'Est de la Région des Plateaux. Thèse de Doctorat, Université de Lomé, Togo,.

[9] Corniaux, C. (2012) Actualisation des données sur le commerce du bétail au Togo: Circuits, marchés et consommation de viande bovine. Montpellier, France, Rapport CIRAD Département ES N²012-208 705.

[10] WHO (2011) Guidelines for Drinking-Water Quality. 4th Edition.

[11] Groupement Egis Bceom International-IGA-GTI (2011) Projet de réhabilitation et de création de points d'eau dans la Région des Plateaux, Volet $n^{\circ} 2$, Volume 1 : Rapport Final.

[12] Güler, C., Thyne, G.D., McCray, J.E. and Turner, K.A. (2002) Evaluation of Graphical and Multivariate Statistical Methods for Classification of Water Chemistry Data. Hydrogeology Journal, 10, 455-474. https://doi.org/10.1007/s10040-002-0196-6

[13] Thyne, G., Güler, C. and Poeter, E. (2004) Sequential Analysis of Hydrochemical Data for Watershed Characterization. Groundwater, 42, 711-723.

https://doi.org/10.1111/j.1745-6584.2004.tb02725.x

[14] Cloutier, V., Lefebvre, R., Therrien, R. and Savard, M.M. (2008) Multivariate Statistical Analysis of Geochemical Data as Indicative of the Hydrogeochemical Evolution of Groundwater in a Sedimentary Rock Aquifer System. Journal of Hydrology, 353, 294-313. https://doi.org/10.1016/j.jhydrol.2008.02.015

[15] Moya, C.E., Raiber, M., Taulis, M. and Cox, M.E. (2015) Hydrochemical Evolution and Groundwater Flow Processes in the Galilee and Eromanga Basins, Great Artesian Basin, Australia: A Multivariate Statistical Approach. Science of the Total Environment, 508, 411-426. https://doi.org/10.1016/j.scitotenv.2014.11.099

[16] Emvoutou, H.C., et al. (2018) Geologic Factors Controlling Groundwater Chemistry in the Coastal Aquifer System of Douala/Cameroon: Implication for Groundwater System Functioning. Environmental Earth Sciences, 77, Article No. 219. https://doi.org/10.1007/s12665-018-7400-z

[17] Wanda, E., Monjerezi, M., Mwatseteza, J.F. and Kazembe, L.N. (2011) Hydro-Geochemical Appraisal of Groundwater Quality from Weathered Basement Aquifers in Northern Malawi. Physics and Chemistry of the Earth, Parts $A / B / C, 36$, 1197-1207. https://doi.org/10.1016/j.pce.2011.07.061

[18] Merchan, D., Auque, L.F., Acero, P., Gimeno, M.J. and Causape, J. (2015) Geochemical Processes Controlling Water Salinization in an Irrigated Basin in Spain: Identification of Natural and Anthropogenic Influence. Science of the Total Environment, 502, 330-343. https://doi.org/10.1016/j.scitotenv.2014.09.041

[19] Menció, A., et al. (2016) Nitrate Pollution of Groundwater; All Right..., But Nothing Else? Science of the Total Environment, 539, 241-251. https://doi.org/10.1016/j.scitotenv.2015.08.151

[20] Akpataku, K.V. (2018) Apports de l'hydrogéochimie et de l'hydrologie isotopique à la compréhension du fonctionnement des aquifères en zones de socle dans la Région des Plateaux au Togo. Thèse de Doctorat Unique, Université de Lomé, Togo.

[21] Kintché, K., Guibert, H., Sogbedji, J.M., Lévêque, J. and Tittonell, P. (2010) Carbon Losses and Primary Productivity Decline in Savannah Soils under Cotton-Cereal Rotations in Semiarid Togo. Plant Soil, 336, 469-484. https://doi.org/10.1007/s11104-010-0500-5

[22] Sylvain, J.P., Collart, J., Aregba, A. and Godonou, S. (1986) Notice explicative de la carte géologique 1/500.0000 è du Togo. Direction Generale des Mines de la Géologie 
et du Bureau National de Recherches Minières Mémoire $\mathrm{N}^{\circ} 6$.

[23] Rodier, J., Legube, B., Merlet, N., et al. (2009) L'analyse de l'eau. 9e Edition, Dunod, Paris.

[24] Fritz, S.J. (1994) A Survey of Charge-Balance Errors on Published Analyses of Potable Ground and Surface Waters. Groundwater, 32, 539-546. https://doi.org/10.1111/j.1745-6584.1994.tb00888.x

[25] Ledesma-Ruiz, R., Pastén-Zapata, E., Parra, R., Harter, T. and Mahlknecht, J. (2015) Investigation of the Geochemical Evolution of Groundwater under Agricultural Land: A Case Study in Northeastern Mexico. Journal of Hydrology, 521, 410-423. https://doi.org/10.1016/j.jhydrol.2014.12.026

[26] Kaiser, H.F. (1960) The Application of Electronic Computers to Factor Analysis. Educational and Psychological Measurement, 20, 141-151. https://doi.org/10.1177/001316446002000116

[27] Dieng, N.M., Orban, P., Otten, J., Stumpp, C., Faye, S. and Dassargues, A. (2017) Temporal Changes in Groundwater Quality of the Saloum Coastal Aquifer. Journal of Hydrology: Regional Studies, 9, 163-182. https://doi.org/10.1016/j.ejrh.2016.12.082

[28] Akpataku, K.V., Gnazou, M.D.-T., Bawa, L.M., Djaneye, G. and Faye, S. (2016) Etude hydrogéochimique du système aquifère granito-gneissique dans la préfecture du Moyen-Mono, Togo. Afrique Science, 12, 38-53.

[29] Akpataku, K.V., et al. (2019) Hydrochemical and Isotopic Characterization of Groundwater in the Southeastern Part of the Plateaux Region, Togo. Hydrological Sciences Journal, 64, 983-1000. https://doi.org/10.1080/02626667.2019.1615067

[30] Agbossoumondé, Y., Ménot, R.-P., Paquette, J.L., Guillot, S., Yéssoufou, S. and Perrache, C. (2007) Petrological and Geochronological Constraints on the Origin of the Palimé-Amlamé granitoids (South Togo, West Africa): A Segment of the West African Craton Paleoproterozoic Margin Reactivated during the Pan-African Collision. Gondwana Research, 12, 476-488.

https://doi.org/10.1016/j.gr.2007.01.004

[31] Chacha, N., Njau, K.N., Lugomela, G.V. and Muzuka, A.N.N. (2018) Hydrogeochemical Characteristics and Spatial Distribution of Groundwater Quality in Arusha Well Fields, Northern Tanzania. Applied Water Science, 8, 118. https://doi.org/10.1007/s13201-018-0760-4

[32] Anornu, G., Gibrilla, A. and Adomako, D. (2017) Tracking Nitrate Sources in Groundwater and Associated Health Risk for Rural Communities in the White Volta River Basin of Ghana Using Isotopic Approach ( $\delta 15 \mathrm{~N}, \delta 18 \mathrm{O}$ NO 3 and 3 H). Science of the Total Environment, 603-604, 687-698. https://doi.org/10.1016/j.scitotenv.2017.01.219

[33] Loh, Y.S.A., Akurugu, B.A., Manu, E. and Aliou, A.-S. (2020) Assessment of Groundwater Quality and the Main Controls on Its Hydrochemistry in Some Voltaian and Basement Aquifers, Northern Ghana. Groundwater for Sustainable Development, 10, Article ID: 100296. https://doi.org/10.1016/j.gsd.2019.100296

[34] Bafai, D.D., Koriko, M., Tchegueni, S., Tchangbedji, G., Merlina, G. and Sarakha, M. (2018) Evaluation of Soil Contamination in Cotton Farming Areas of Togo by Organochlorinated Pesticides: Case of the Experimental Station of Kolokope. International Journal of Innovation and Applied Studies, 24, 1131-1138.

[35] Walraevens, K., Bakundukize, C., Mtoni, Y.E. and Van Camp, M. (2018) Understanding the Hydrogeochemical Evolution of Groundwater in Precambrian Basement Aquifers: A Case Study of Bugesera Region in Burundi. Journal of Geochemi- 
cal Exploration, 188, 24-42. https://doi.org/10.1016/j.gexplo.2018.01.003

[36] Jarvis, A., Reuter, H.I., Nelson, A. and Guevara, E. (2008) Hole-Filled SRTM for the Globe. Version 4. http://srtm.csi.cgiar.org

[37] Yao, L.-X., et al. (2007) Salinity of Animal Manure and Potential Risk of Secondary Soil Salinization through Successive Manure Application. Science of the Total Environment, 383, 106-114. https://doi.org/10.1016/j.scitotenv.2007.05.027

[38] Bouzourra, H., Bouhlila, R., Elango, L., Slama, F. and Ouslati, N. (2015) Characterization of Mechanisms and Processes of Groundwater Salinization in Irrigated Coastal Area Using Statistics, GIS, and Hydrogeochemical Investigations. Environmental Science and Pollution Research, 22, 2643-2660.

https://doi.org/10.1007/s11356-014-3428-0

[39] Srinivasamoorthy, K., Gopinath, M., Chidambaram, S., Vasanthavigar, M. and Sarma, V.S. (2014) Hydrochemical Characterization and Quality Appraisal of Groundwater from Pungar Sub Basin, Tamilnadu, India. Journal of King Saud University-Science, 26, 37-52. https://doi.org/10.1016/j.jksus.2013.08.001

[40] Jankowski, J. and Acworth, R.I. (1997) Impact of Debris-Flow Deposits on Hydrogeochemical Processes and the Development of Dryland Salinity in the Yass River Catchment, New South Wales, Australia. Hydrogeology Journal, 5, 71-88.

https://doi.org/10.1007/s100400050119

[41] Faye, S., Maloszewski, P., Stichler, W., Trimborn, P., Cisse Faye, S. and Becaye Gaye, C. (2005) Groundwater Salinization in the Saloum (Senegal) Delta Aquifer: Minor Elements and Isotopic Indicators. Science of the Total Environment, 343, 243-259. https://doi.org/10.1016/j.scitotenv.2004.10.001

[42] Rajmohan, N. and Elango, L. (2003) Identification and Evolution of Hydrogeochemical Processes in the Groundwater Environment in an Area of the Palar and Cheyyar River Basins, Southern India. Environmental Earth Sciences, 46, 47-61.

[43] Khan, A., Umar, R. and Khan, H.H. (2015) Significance of Silica in Identifying the Processes Affecting Groundwater Chemistry in Parts of Kali Watershed, Central Ganga Plain, India. Applied Water Science, 5, 65-72. https://doi.org/10.1007/s13201-014-0164-Z 